Journal of Thermal Engineering, Vol. 7, No. 3, pp. 677-689, March, 2021

Yildiz Technical University Press, Istanbul, Turkey

\title{
EXPERIMENTAL INVESTIGATION ON THERMAL BEHAVIOR OF HYBRID SINGLE SLOPE SOLAR STILL
}

\author{
Anshika Rani ${ }^{1}$, Ravi Kant ${ }^{2}$, S. Suresh ${ }^{1 *}$, Anil Kumar²
}

\begin{abstract}
Solar energy is one of the most common and eco-friendly non-conventional types of energy source which is having various applications like purification of saline water. The experimental study of the present research work has been performed at the M.A.N.I.T, Bhopal M.P, India (latitude: $23^{\circ} 12^{\prime} 51^{\prime \prime} \mathrm{N}$, longitude: $77^{\circ} 25^{\prime} 0^{\prime \prime} \mathrm{E}$ ) in the month of January 2018. The investigation has been performed on single slope solar still coupled with a flat plate solar collector to examine the thermal behaviour of the solar system and results have been presented in natural and forced convection mode. The overall efficiency reached up to $9.86 \%$ in natural mode where as $16.70 \%$ in forced mode. Therefore, forced mode solar still option is better and preferred.
\end{abstract}

Keywords: Single Slope Solar Still, Natural Convection, Forced Convection, Internal Heat Transfer Coefficient, External Heat Transfer Coefficient

\section{INTRODUCTION}

Water is known as the nectar found on earth, as it is a necessary part of the survival of any life. In excess of two third of the world's surface is covered with water from which, Ninety-seven percent of the water has been found in seas and oceans which is extremely salty water $(30000-35000 \mathrm{ppm})$ as a result of which it is not useable for social utilization [1]. Rest $3 \%$ of non-salty water supplies for domestic purpose. Due to various kinds of development, activity by human the non-salty water is also polluted with various kinds of microbes and contaminations like arsenic, fluoride, chloride etc. These are responsible for various diseases (for example typhoid, cholera, malaria etc.). The need of useable water will develop step by step because of rapid increment in populace and quick industrial development. More water purification methods are being generated to clean water shortage on the earth. It is a generally accredited process for changing over salty or polluted water into potable water by the utilization of thermal energy. Solar energy is a perfect answer for fueling the refining procedure, which is atmosphere friendly, free of cost and accessible in large quantity throughout the planet [2,3]. Solar desalination (SD) is a stand out among all other methods for purifying salty water. Solar still is broadly used as a part of the SD process, yet the efficiency and cost-effectiveness of a solar still is low when compared with other refining procedures [4,5]. Thus it is essential to upgrade the productivity of solar still through improving the conventional design parameters and operative methods [5].

Tiwari and Tiwari [6] done the analysis in summer season for passive single SD system for the effect of water depth on evaporative heat tran4sfer coefficient. Experiments were done on single slope solar still with $30^{\circ}$ top glass inclination and south facing for $24 \mathrm{~h}$ for different water depths from $0.04 \mathrm{~m}$ to $0.18 \mathrm{~m}$. More yield was collected at higher water depth in the still due to the effect of storage during off sunshine hours. Natural convection heat transfer of single slope solar still was numerically studied by Rahbar and Esfahani [7]. Rayleigh Number varied from $5 \times 10^{6}$ to $5 \times 10^{7}$ and aspect ratio was between 2.5 and 5.5.The comparison of theoretical and experimental performance results for a single slope still was given by Agrawal et al.[1]. Experiments performed at different water depth 2,4,6,8 and $10 \mathrm{~cm}$ in the solar still. Heat transfer coefficients for different water depth also calculated. Solar still gives the higher distillate output at minimum water depth, and the values of radiative and convective heat transfer coefficients were less than evaporative heat transfer coefficient. Kumar and Tiwari [8] developed a regression analysis based thermal model for different Grashof number range in the SD system and also calculated the values of $\mathrm{C}$ and $\mathrm{n}$ based on the experimental

This paper was recommended for publication in revised form by Regional Editor Baha Zafer

${ }^{1}$ Department of Chemical Engineering, Maulana Azad National Institute of Technology Bhopal-462 003, India

${ }^{2}$ Department of Mechanical Engineering, Delhi Technological University, Delhi-110042, India

${ }^{*}$ E-mail address: sureshpecchem@gmail.com, anilkumar76@dtu.ac.in

Orcid id: 0000-0002-1424-9259, 0000-0002-2846-4347, 0000-0001-8758-7841, 0000-0000-5494-0725

Manuscript Received 13 February 2019, Accepted 30 April 2019 
data for passive and active SD system. Results showed that it was necessary to carry out an experiment on a particular model of still for the given climatic condition to estimate the values of $\mathrm{C}$ and $\mathrm{n}$ to find various heat transfer coefficients. Hidouri et al. [9] calculated the mass flow rate by using three groups of relationship for with and without solar distiller. The theoretical results calculated by Lewis number correlation compared with experimental results, and both results show the good agreements. Hybrid solar sill gives a higher yield than simple solar still. Kumar and Tiwari [10] attempted to estimate the internal heat transfer coefficient of a basin hybrid (PV/T) active solar still. The internal heat transfer coefficients by the application of several thermal models suggested by several researchers have been calculated. The average yearly values of convective heat transfer coefficient for both the systems have been found at $0.05 \mathrm{~m}$ depth of water. By various thermal models, internal heat transfer coefficient for single and double slope passive solar stills evaluated by Dwivedi and Tiwari [11] in summer and winter seasons for three different water depths ( 0.01, 0.02 and $0.03 \mathrm{~m}$ ). It was found that single slope solar still gives better output than double slope solar still. Phadatare and Verma [12] calculated the cover materials effect on mass and heat transfer coefficients and still yield. The glass cover and acrylic cover used for this study. Evaporative heat transfer coefficient was found more for the glass cover as compared to acrylic cover. Therefore, glass cover gives a higher distillate output than the acrylic cover. Vinoth et al. [13] carried out the experiment with different kinds of samples like tap water, seawater and dairy industry wastewater in a solar still. The maximum efficiency and highest yield of the still were $30 \%$ and $1.4 \mathrm{~L} / \mathrm{m}^{2}$, respectively. Tripathi and Tiwari [2] investigated the effects of different water depths on the convective heat transfer coefficient for passive and active SD system. The experiment performed for 24 hours in winter. The results show that more distillate outlet collected in the off sunshine hours than the sunshine hours for higher depths of water because of storage effect. Sakthivel et al.[14] conducted the experiment to give the large evaporation surface and used the latent heat of condensation with jute cloth as energy storage media on solar still. The jute cloth set aside perpendicularly in the center of the solar still water and combined it with the rear wall of the solar still. The performance of both the solar stills compared under the same condition. The output from the renewing still with jute cloth increase up to $20 \%$ with and efficiency up to $8 \%$.

After considering the above research, it was found that very few researches has shown the natural and forced type solar stills. The comparison between these two are lacks in the open literature. Based on this fact, the authors' focused in the current research on the comparison of natural and forced type solar still system in which internal and external heat transfer coefficients have been calculated.

\section{EXPERIMENTAL SETUP}

The SD system is fabricated to investigate the effect of different operating parameters under the similar seasonal effect of the center part of India at Bhopal (Latitude: $23^{\circ} 12^{\prime} 51^{\prime \prime} \mathrm{N}$, Longitude: $77^{\circ} 25^{\prime} 0^{\prime \prime} \mathrm{E}$ ). Single slope solar still is attached with flat plate collector (FPC) directly in natural convection mode while in forced convection mode, there was a pump used between the outlet of the still and inlet of the collector and the flowrate from the pump is 3.5 $\mathrm{L} / \mathrm{min}$. In the open literature, consideration of heat loses during a cloudy day and night hours are lacking which is considered in the present work. The SD system was wrapped by black color polythene to prevent heat loses and the pumping system was stopped at night hours to reduce heat loses. A cross-sectional perspective of single slope solar still in natural prepared of Fiber-Reinforced Plastic(FRP) is appeared in Figure 1, and the base surface of the still was painted black for acquiring more absorptivity and a glass cover $3 \mathrm{~mm}$ thick covers the still. The cross-sectional view of single slope forced solar still is shown in Figure 2. The area of the still and FPC was taken as 1 and $2 \mathrm{~m}^{2}$, respectively. FPC is of TATA POWER Company. The depth of solar still was $5.08 \mathrm{~cm}$. Glass is fixed on the side of the FRP frame, and an inclination of $23^{\circ}$ is given to the glass cover, which is same as the latitude of Bhopal. To avoid vapour leakage, glass putty used as a sealing material for filling the gap between the solar still and glass cover. Plastic vessels used to collect the distillate yield. The important design parameters of the both natural and forced mode systems are shown in Table 1. 


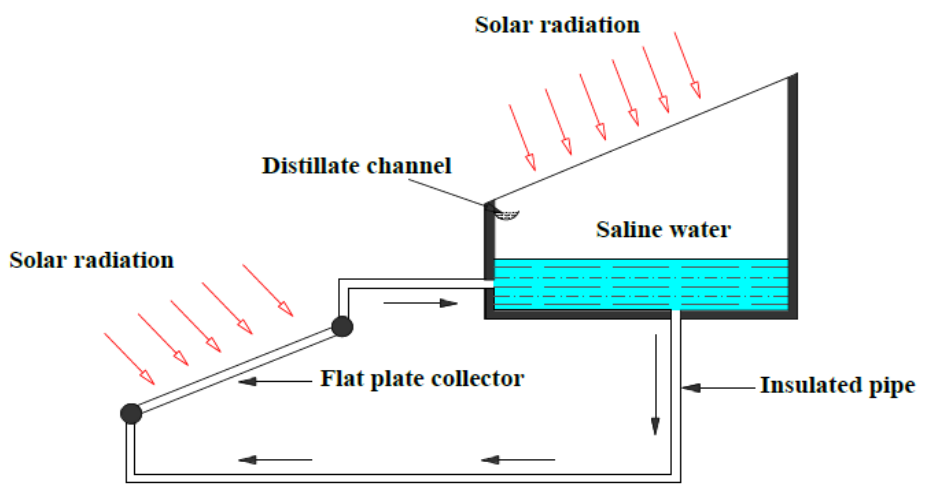

Figure 1. Cross-sectional view of single slope natural convection active solar still

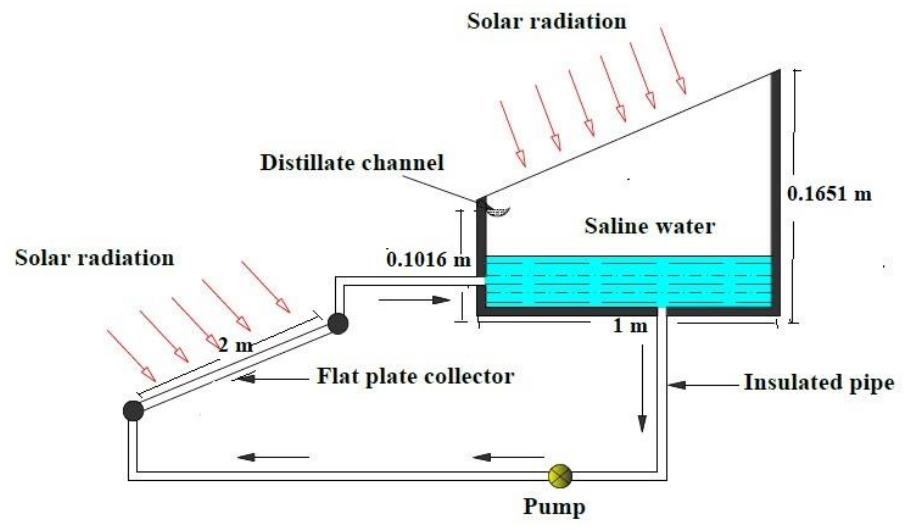

Figure 2. Cross-sectional view of single slope forced convection active solar still

Observations were made for 15 hours from 6:00am to 8:00 pm in the month of January $.0 .25 \mathrm{~m}$ is the average spacing between the glass cover and water surface. The parameters that are measured every hour for a period of 15 hours at the full depth are; Global radiation on collector, Diffused radiation on collector, Ambient temperature, Velocity of air on collector, Inner glass temperature, Outer glass temperature, Vapor temperature just above the water surface, Water temperature, Inlet collector temperature, Outlet collector temperature and Distillate output.

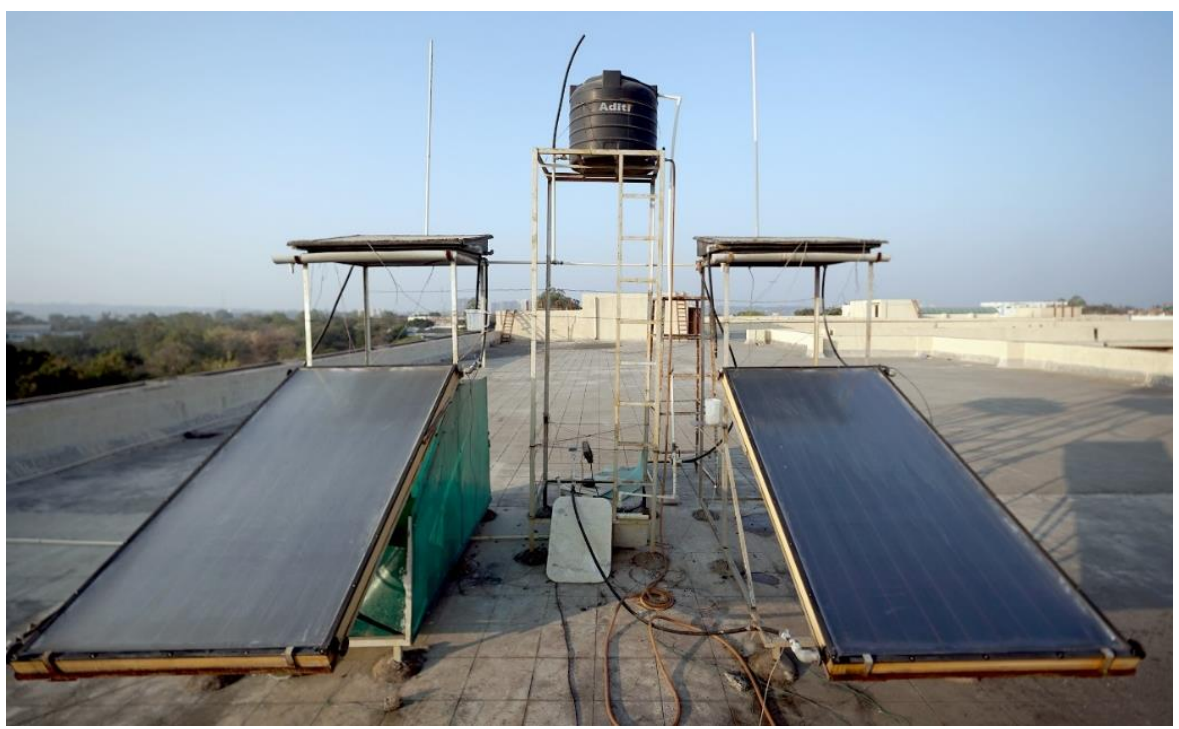

Figure 3. Picture of the experimental setup 
Journal of Thermal Engineering, Research Article, Vol. 7, No. 3, pp. 677-689, March, 2021

Table 1. Dimensions of natural and forced modes solar desalination setup

\begin{tabular}{|l|l|l|}
\hline S. No. & Dimension & Unit \\
\hline 1 & Length of Solar Still & $1 \mathrm{~m}$ \\
\hline 2 & Width of solar still & $1 \mathrm{~m}$ \\
\hline 3 & Front height of solar still & $0.1016 \mathrm{~m}$ \\
\hline 4 & Back height of solar still & $0.1651 \mathrm{~m}$ \\
\hline 5 & Length of Solar collector & $2 \mathrm{~m}$ \\
\hline 6 & Width of solar collector & $1 \mathrm{~m}$ \\
\hline 7 & Inclination angle according to the latitude & $23.5^{\circ}$ \\
\hline
\end{tabular}

\section{UNCERTAINTY ANALYSIS}

The calibrated iron -constantan thermocouples and a voltmeter measured water temperature, inner glass temperature, outer glass temperature, vapour temperature, inlet collector temperature and outlet collector temperature. With the help of voltmeter (EEE-Tech MAS 830L), voltage of above junction is recorded and then converted into temperatures by the K-type thermocouple table. The measuring cylinder of least count of $10 \mathrm{ml}$ measured the distillate output, Relative humidity and ambient temperature are recorded by hygrometer (testo 608-H1). Global solar radiation and diffused solar radiation are measured by the solar power meter (AMPROBE Solar-100) with least count $2 \mathrm{~W} / \mathrm{cm}$, and air velocity is measured by air velocity meter (testo 410-1). The SD setup is placed in south-west direction with the glass cover inclination facing the south for receiving the maximum solar radiation. Experiments are done at the Bhopal (M.P.) center part of India in the month of January. The solar still is filled with tap water collected from M.A.N.I.T., Bhopal. The distillate output collected and operating parameter is measured every hour from 6:00 am to 8:00 pm. Figure 4 shows the variation of different ambient parameters, solar intensity and diffuse solar intensity with time.

The uncertainty in measurement of observed parameters are calculated as (Singh et al., Tiwari and Tiwari, Tiwari et al.) [15-17]. The total uncertainty in global and diffuse solar radiation measurement $W_{\text {Solar radiation,total }}$ can be occurred from readings errors and solar power meter.

$$
\begin{aligned}
& W_{\text {Solar radiation,total }}=\left[W_{\text {solar power meter }}^{2}+W_{\text {Reading }}^{2}\right]^{1 / 2} \\
& W_{\text {Solar radiation,total }}=\left[0.1^{2}+0.2^{2}\right]^{1 / 2}=0.2236
\end{aligned}
$$

The total uncertainty in temperature measurement $W_{\text {Temp,total }}$ can be occurred from $\mathrm{K}$ type thermocouple wire, Hygrometer and readings errors.

$$
\begin{aligned}
& W_{\text {Temp,total }}=\left[W_{K \text {-type thermocouple wire }}^{2}+W_{\text {Hygrometer }}^{2}+W_{\text {Reading }}^{2}\right]^{1 / 2} \\
& W_{\text {Temp,total }}=\left[0.2^{2}+0.1^{2}+0.2^{2}\right]^{1 / 2}=0.3
\end{aligned}
$$

The total uncertainty in relative humidity measurement $W_{R h, t o t a l}$ can be occurred from hygrometer and readings error.

$$
\begin{aligned}
& W_{R h, \text { total }}=\left[W_{\text {Hygrometer }}^{2}+W_{\text {Reading }}^{2}\right]^{1 / 2} \\
& W_{R h, \text { total }}=\left[0.1^{2}+0.1^{2}\right]^{1 / 2}=0.14
\end{aligned}
$$

The total uncertainty in wind velocity measurement $W_{V, \text { total }}$ can be occurred from air velocity meter and readings errors.

$$
\begin{aligned}
& W_{V, \text { total }}=\left[W_{\text {Air Velocity Meter }}^{2}+W_{\text {Reading }}^{2}\right]^{1 / 2} \\
& W_{V, \text { total }}=\left[0.1^{2}+0.1^{2}\right]^{1 / 2}=0.14
\end{aligned}
$$


Journal of Thermal Engineering, Research Article, Vol. 7, No. 3, pp. 677-689, March, 2021

The total uncertainty in hourly collected yield measurement $W_{\text {Hourly collected,total }}$ occurred from evaporation of water takes place during collection of water and reading errors.

$$
\begin{aligned}
& W_{\text {Hourly collected,total }}=\left[W_{\text {Air Velocity Meter }}^{2}+W_{\text {Reading }}^{2}\right]^{1 / 2} \\
& W_{\text {Hourly collected,total }}=\left[1^{2}+1^{2}\right]^{1 / 2}=1.41
\end{aligned}
$$

Total uncertainty during the experiment $W_{E x \text {,total }}$

$$
\begin{aligned}
& W_{E x, \text { total }}=\left[W_{\text {Solar radiation,total }}+W_{\text {Temp,total }}+W_{R h, \text { total }}+W_{V, \text { total }}+W_{\text {Hourly collected,total }}\right]^{1 / 2} \\
& W_{E x, \text { total }}=\left[0.2236^{2}+0.3^{2}+0.14^{2}+0.14^{2}+1.41^{2}\right]^{1 / 2}= \pm 2.21 \%
\end{aligned}
$$

The error analysis was calculated based on the above equations and found that very low value $( \pm 2.21 \%)$ within acceptable limit.

\section{THERMAL MODELING}

\section{External Heat Transfer Coefficients}

The external heat transfer, radiation and convection losses from the glass cover to the outside atmosphere are calculated as Tiwari [18]:

$$
\begin{gathered}
h_{r g}=\frac{\epsilon_{g} \sigma\left[\left(T_{o g s}+273\right)^{4}-\left(T_{\text {sky }}+273\right)^{4}\right]}{\left(T_{g}-T_{a}\right)} \\
h_{c g}=2.8+3.0 \mathrm{~V}
\end{gathered}
$$

Where $\mathrm{V}$ is the velocity in $\mathrm{m} / \mathrm{sec}$ and $\sigma$ is Stephan's Boltzmann constant. $\epsilon_{g}$ is the emissivity of the glass.

\section{Internal Heat Transfer Coefficients}

Internal heat transfer, convection and evaporation losses from the water surface to glass cover in the distillation unit can be expressed as:

$$
q_{c w}=h_{c w}\left(T_{w}-T_{g}\right)
$$

The coefficient $h_{c w}$ can be determined by the relation

$$
\begin{gathered}
N_{u}=\frac{h_{c w} d_{f}}{K_{f}}=C\left(G_{r} P_{r}\right)^{n} \\
G_{r}=\frac{d_{f}^{3} \rho_{f}^{3} g \beta^{\prime}}{\mu_{f}^{2}} \Delta T \\
P_{r}=\frac{\mu_{f} C_{f}}{K_{f}} \\
\Delta T^{\prime}=\left[\begin{array}{c}
\left(P_{w 0}-P_{i g s 0}\right)\left(T_{w 0}+273\right) \\
268900-P_{w 0}
\end{array}\right] \\
h_{c w}=\frac{k_{v}}{X} C\left(G_{r} P_{r}\right)^{n}
\end{gathered}
$$

For a normal operating temperature range, say $50^{\circ} \mathrm{C}$ and $\Delta T^{\prime}=17^{\circ} \mathrm{C}$, the expression for Grashof number given above is reduced to following expression and Dunkle derived the following expression for the convective heat transfer coefficient 


$$
\begin{gathered}
G_{r}=2.81 \times 10^{7} d_{f}^{3} ; \quad h_{\text {cwDunkle }}=0.884 \times\left[\left(T_{w}-T_{i g s}\right)+\frac{\left.\left[P_{w}-P_{g}\right]\left(T_{w}+273\right)\right]}{268900-\left(P_{w}\right)}\right]^{\frac{1}{3}} \\
h_{\text {ewDunkle }}=16.273 \times 10^{-3} h_{c w} \frac{P_{w}-P_{g}}{T_{w}-T_{g}}
\end{gathered}
$$

where saturation vapour pressure corresponding to the temperature can be calculated as:

$$
\begin{gathered}
P(T)=\exp \left(25.317-\frac{5144}{T+273}\right) \\
h_{r w}=\epsilon_{e f f} \sigma\left[\left(T_{w}+273\right)^{2}+\left(T_{i g s}+273\right)^{2}\right]\left[T_{w}+T_{i g s}+546\right]
\end{gathered}
$$

For comparison of evaporative heat transfer coefficient $h_{e w}$ calculated by Cooper [20]

$$
h_{e w}=16.273 \times 10^{-3} h_{c w} \frac{P_{w}-P_{g}}{T_{w}-T_{i g s}}
$$

\section{Thermal Performance}

The expression for hourly efficiency $\left(\eta_{\mathrm{i}}\right)$, can be given by Tiwari [18], Rani et al.[19]:

$$
\eta \mathrm{i}=\frac{\mathrm{mL}}{\mathrm{I}(\mathrm{t}) A_{s}}
$$

Overall thermal efficiency of distiller unit in the passive and active modes of operation can be mathematically expressed as,

$$
\eta_{\text {active }}=\frac{\sum \mathrm{mL}}{\left[A_{s} S I(t) d t+N A_{c} \int I^{\prime}(t) d t\right]} \times 100
$$

The rate of internal heat transfer per unit area from water surface to the glass cover obtained by

$$
q_{\text {ew internal }}=h_{c w}\left(T_{w}-T_{g}\right)
$$

The rate of external heat transfer per unit area from water surface to the glass cover obtained by

$$
q_{\text {ew external }}=h_{c g}\left(T_{w}-T_{g}\right)
$$

All the above relations for different affecting parameters are calculated in the present study.

\section{RESULTS AND DISCUSSION}

The observation for the ambient parameters and solar intensity for the typical days of winter months of the experimental setup are shown in Figure 4(A).

Figure 4(A) shows the different parameters relative humidity, the velocity of air, ambient temperature, solar radiation and diffuse solar radiation for natural and forced type solar still respectively. In Figure 4(A) the maximum value of relative humidity $\left(\mathrm{Rh}_{\mathrm{a}}\right)$ obtained is $64.1 \%$ in the time interval of 7:00 am to 8:00 am. The velocity of air $\left(\mathrm{V}_{\mathrm{a}}\right)$ is found a maximum of about $1.9 \mathrm{~m} / \mathrm{s}$ at the time interval of 12:00 pm to 1:00 pm. The maximum value for Ambient temperature $\left(\mathrm{T}_{\mathrm{a}}\right)$, obtained is $36.4{ }^{\circ} \mathrm{C}$ in between 3:00 pm to 4:00 pm. Maximum solar radiation $\left(\mathrm{I}_{\mathrm{gr}}\right)$ obtained is 950.5 $\mathrm{W} / \mathrm{m}^{2}$ in the duration of $12: 00 \mathrm{pm}$ to 1:00 pm and the maximum diffused solar radiation $\left(\mathrm{I}_{\mathrm{dr}}\right)$ obtained is $143 \mathrm{~W} / \mathrm{m}^{2}$ in the duration 1:00 pm to 2:00 pm. While for forced type solar still the maximum value of relative humidity $\left(\mathrm{Rh}_{\mathrm{a}}\right)$ obtained is $64.1 \%$ in the time interval of 7:00 am to 8:00 am. The velocity of air $\left(\mathrm{V}_{\mathrm{a}}\right)$ is found a maximum of about $1.9 \mathrm{~m} / \mathrm{s}$ at the time interval of 12:00 pm to 1:00 pm. The maximum value for Ambient temperature $\left(\mathrm{T}_{\mathrm{a}}\right.$ ), obtained is $38.5{ }^{0} \mathrm{C}$ in between 4:00 pm to 5:00 pm. Maximum solar radiation $\left(\mathrm{I}_{\mathrm{gr}}\right)$ obtained is $970.85 \mathrm{~W} / \mathrm{m}^{2}$ in the duration of 1:00 pm to 2:00 $\mathrm{pm}$. and the maximum diffused solar radiation $\left(\mathrm{I}_{\mathrm{dr}}\right)$ obtained is $143 \mathrm{~W} / \mathrm{m}^{2}$ in the duration $1: 00 \mathrm{pm}$ to $2: 00 \mathrm{pm}$. Temperature dependent Physical properties of vapor are shown in Table 2. 


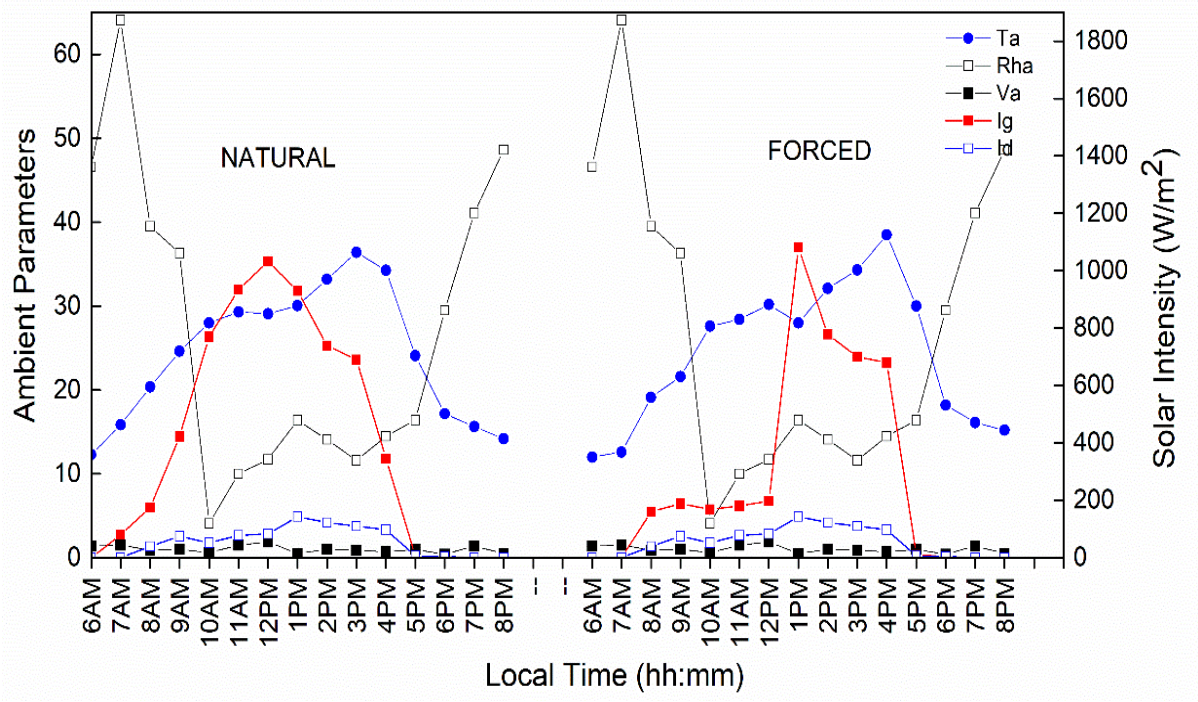

(A)

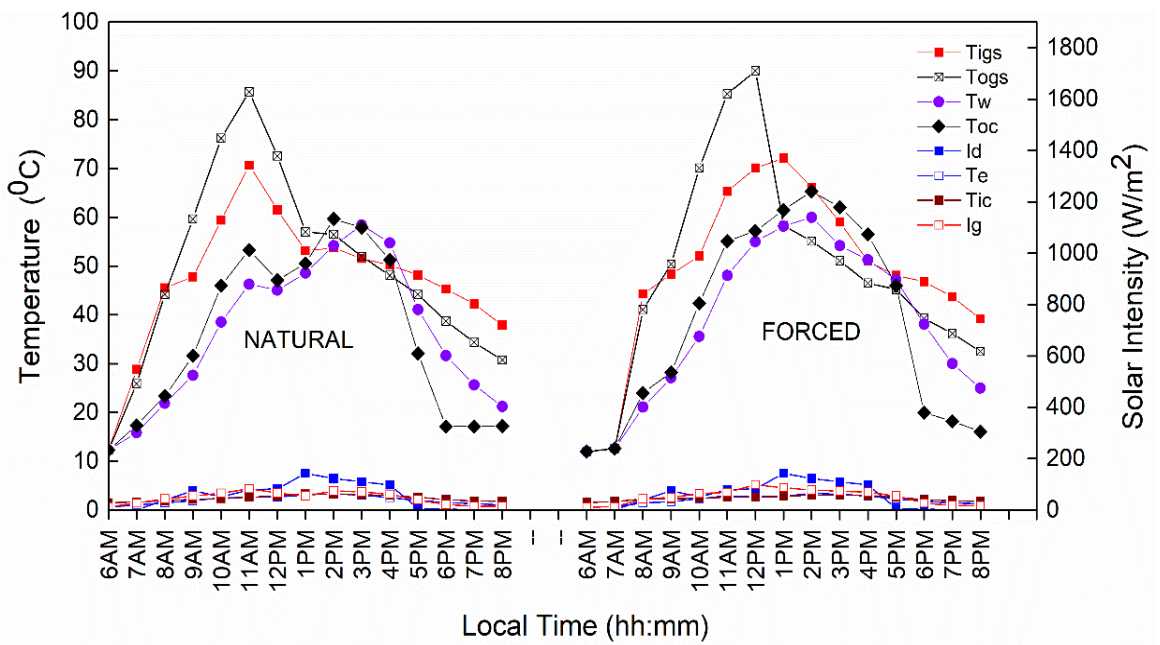

(B)

Figure 4. Variation of Ambient parameter and Different temperature with time (A) Ambient parameter (B) Different temperature

The hourly observed values of inner glass temperature, outer glass temperature, water temperature, vapour temperature; collector inlet temperature and collector outlet temperature for natural convection are shown in Figure 4(B) for natural and forced type solar still. For natural type solar still, the maximum value of inner glass temperature ( $\mathrm{T}_{\text {igs }}$ ) obtained is $59.6^{\circ} \mathrm{C}$ in the time interval of $12: 00 \mathrm{pm}$ to $1: 00 \mathrm{pm}$. The maximum value of the outer glass temperature ( $\mathrm{T}_{\text {ogs }}$ ) obtained is $72.55^{\circ} \mathrm{C}$ in the time interval of $12: 00 \mathrm{pm}$ to $1: 00 \mathrm{pm}$. The maximum value for evaporator temperature $\left(\mathrm{T}_{\mathrm{e}}\right)$, obtained is $59.05{ }^{\circ} \mathrm{C}$ in between 1:00 pm to $2: 00 \mathrm{pm}$. The maximum value for water temperature $\left(\mathrm{T}_{\mathrm{w}}\right)$, obtained is $70.2{ }^{\circ} \mathrm{C}$ in between 1:00 pm to 2:00 pm. The maximum inlet temperature of the collector (Tic) obtained is $59.7{ }^{\circ} \mathrm{C}$ in a time interval of 2:00 pm to $3: 00 \mathrm{pm}$. and the maximum outlet temperature of the collector $\left(\mathrm{T}_{\text {oc }}\right)$ obtained is $74.7^{\circ} \mathrm{C}$ in a time interval of 2:00 pm to 3:00 pm. For forced type solar still, the maximum value of inner glass temperature $\left(\mathrm{T}_{\mathrm{igs}}\right)$ obtained is $72.1^{\circ} \mathrm{C}$ in the time interval of 1:00 pm to 2:00 pm. The maximum value of the outer glass temperature $\left(\mathrm{T}_{\mathrm{ogg}}\right)$ obtained is $90^{\circ} \mathrm{C}$ in the time interval of $12: 00 \mathrm{pm}$ to 1:00 pm. The maximum value for evaporator temperature $\left(\mathrm{T}_{\mathrm{e}}\right)$, obtained is $65.1^{\circ} \mathrm{C}$ in between $2: 00 \mathrm{pm}$ to $3: 00 \mathrm{pm}$. The maximum value for water temperature $\left(\mathrm{T}_{\mathrm{w}}\right)$, obtained is $75.4^{0} \mathrm{C}$ in between 1:00 pm to 2:00 pm. The maximum inlet temperature of the collector $\left(\mathrm{T}_{\text {ic }}\right)$ obtained is $65.3^{0} \mathrm{C}$ in a time interval of 2:00 pm to 3:00 pm. and the maximum outlet temperature of the collector $\left(\mathrm{T}_{\mathrm{oc}}\right)$ obtained is $98.6^{\circ} \mathrm{C}$ in a time interval of 12:00 pm to 1:00 pm. The maximum internal heat transfer for natural convection and forced convection is $0.044 \mathrm{~W} / \mathrm{m}^{2}$ at $1: 00 \mathrm{pm}$ and $0.2264 \mathrm{~W} / \mathrm{m}^{2}$ at $11: 00$ am respectively. The maximum external heat transfer for natural 
convection and forced convection is $0.412 \mathrm{~W} / \mathrm{m}^{2}$ at $12: 00 \mathrm{pm}$ and $1.108 \mathrm{~W} / \mathrm{m}^{2}$ at 11:00 am respectively. The percentages of internal and external heat transfer were $99.41 \%, 98.81 \%$ for forced convection and $76 \%, 89.41 \%$, for natural convection respectively.

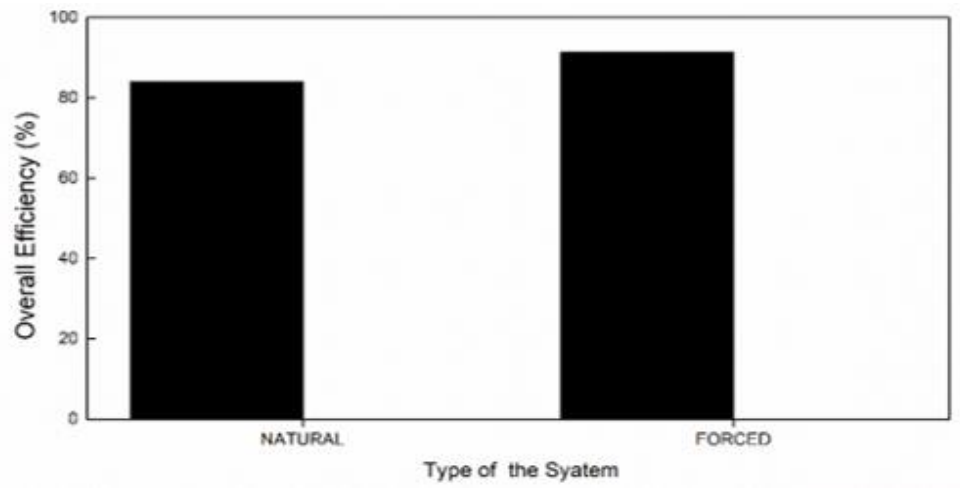

(A)

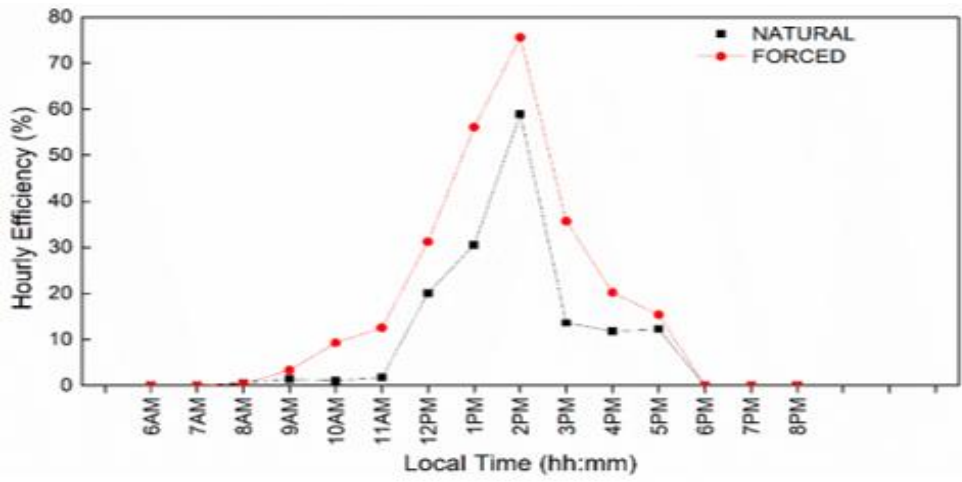

(B)

Figure 5. Variation of Overall Efficiency and Hourly Efficiency with time (A) Overall Efficiency (B) Hourly Efficiency

Figure 5(A) shows the Variation of Overall Efficiency Figure 5(B) shows the hourly Efficiency with time. The overall efficiency for natural convection obtained is $9.86 \%$, and in the forced convection, it is $16.70 \%$. Both the values are calculated in the duration of Day time. The maximum hourly efficiency obtained by natural convection is $58.97 \%$ at the time of 2:00 pm and the maximum hourly efficiency obtained by forced convection is $75.61 \%$ at the time of 2:00 pm.

Table 2. Temperature dependent Physical properties of vapor [16]

\begin{tabular}{|r|l|l|l|}
\hline S. No. & \multicolumn{1}{|c|}{ Physical constants } & \multicolumn{1}{|c|}{ Units } & \multicolumn{1}{c|}{ Expressions $\left[T_{i}(\mathrm{C})=\left(\frac{T_{w}+T_{i g s}}{2}\right)\right]$} \\
\hline 1. & Specific Heat capacity, $\mathrm{C}$ & $\mathrm{J} / \mathrm{kg} \mathrm{K}$ & $999.2+0.143 \mathrm{~T}_{\mathrm{i}}+1.101 \times 10^{-4} \mathrm{~T}_{\mathrm{i}}^{2}-6.7581 \times 10^{-8} \mathrm{~T}_{\mathrm{i}}^{3}$ \\
\hline 2. & Thermal Conductivity, $\mathrm{K}_{\mathrm{v}}$ & $\mathrm{W} / \mathrm{mK}$ & $0.0244+0.7673 \times 10^{-4} \mathrm{~T}_{\mathrm{i}}$ \\
\hline 3. & Viscosity,$\mu$ & $\mathrm{N} . \mathrm{s} / \mathrm{m}^{2}$ & $1.178 \times 10^{-5}+4.620 \times 10^{-8} \mathrm{~T}_{\mathrm{i}}$ \\
\hline 4. & Diffusivity, $\alpha$ & $\mathrm{m}^{2} / \mathrm{s}$ & $7.7255 \times 10^{-10}\left(\mathrm{~T}_{\mathrm{i}}+2730\right)^{1.83}$ \\
\hline 5. & Density, $\rho$ & $\mathrm{kg} / \mathrm{m}^{3}$ & $353.44 /\left(\mathrm{T}_{\mathrm{i}}+273.15\right)$ \\
\hline 6. & Expansion Factor, $\beta^{\prime}$ & $\mathrm{K}^{-1}$ & $1 /\left(\mathrm{T}_{\mathrm{i}}+273.15\right)$ \\
\hline 7. & Acceleration due to Gravity, $\mathrm{g}$ & $\mathrm{m} / \mathrm{s}^{2}$ & 9.81 \\
\hline
\end{tabular}




\section{External Heat Transfer Coefficient}

Heat is loosed from glass cover to outer atmosphere. Hence, top loss heat transfer coefficients are given below. Figure 6(A) and Figure 6(B) represents the external heat transfer coefficients in terms of Convective heat transfer coefficient and Radiative heat transfer coefficients with respect to time respectively. The maximum convective heat transfer coefficient in natural type solar still obtained is $8.5 \mathrm{~W} / \mathrm{m}^{2}{ }^{0} \mathrm{C}$ at the time of $02: 00 \mathrm{pm}$ and the maximum convective heat transfer coefficient through forced type solar still obtained is $11.8 \mathrm{~W} / \mathrm{m}^{20} \mathrm{C}$ at the time of $02: 00 \mathrm{pm}$. The maximum radiative heat transfer coefficient through natural type solar still obtained is $11.65 \mathrm{~W} / \mathrm{m}^{2}{ }^{0} \mathrm{C}$ at the time of 02:00 pm and the maximum radiative heat transfer coefficient through forced type solar still obtained is $15.23 \mathrm{~W} / \mathrm{m}^{2}{ }^{\circ} \mathrm{C}$ at the time of 02:00 pm.

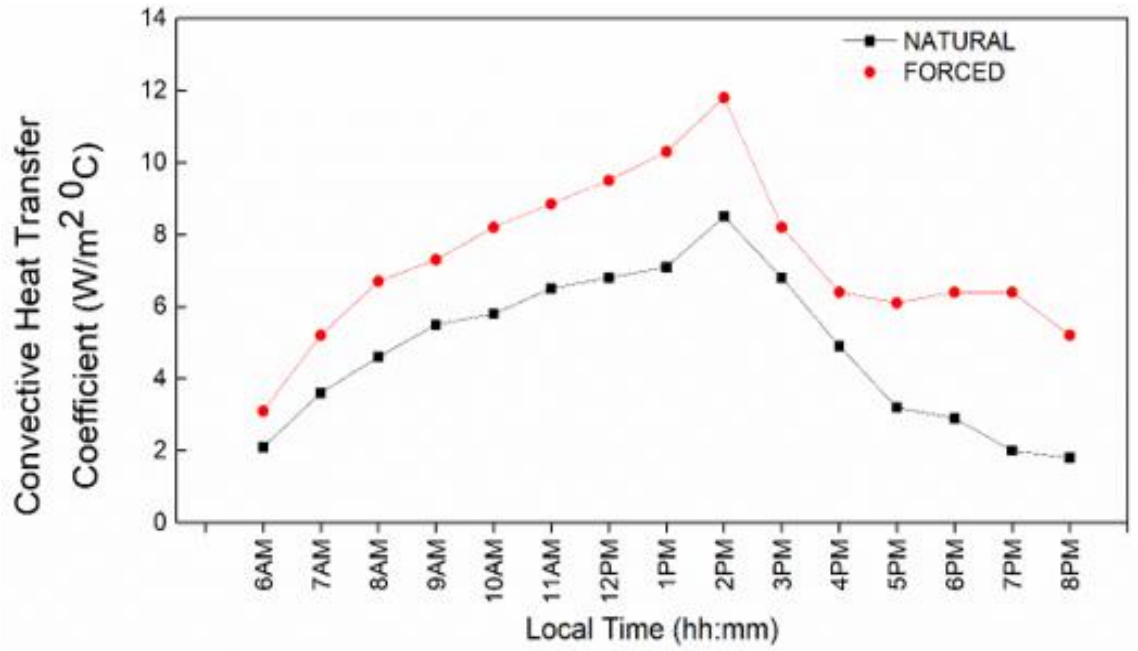

(A)

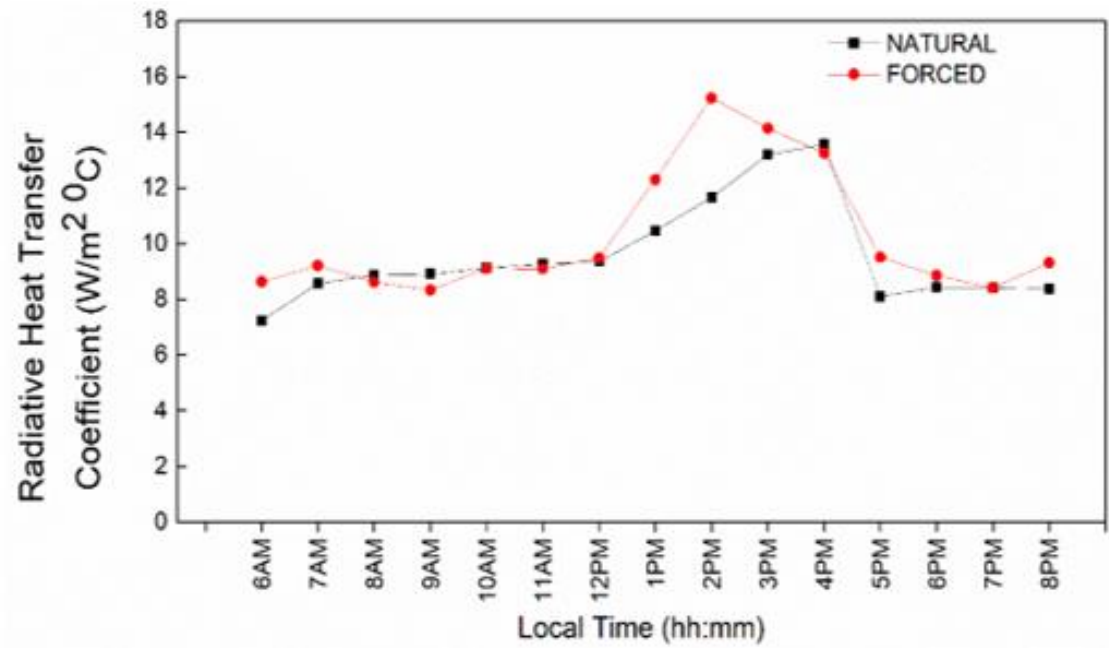

(B)

Figure 6. Variation of external heat transfer coefficient with time (A) Convective heat transfer coefficient (B) Radiative heat transfer coefficient

\section{Internal Heat Transfer Coefficient}

Figure 7(A) and Figure 7(B) internal heat transfer coefficients in terms of Convective heat transfer coefficient and Evaporative heat transfer coefficients with respect to time. The maximum value for convective heat transfer coefficient $\left(\mathrm{h}_{\mathrm{cw}}\right)$ in natural type solar still is $1.12 \mathrm{~W} / \mathrm{m}^{2}{ }^{0} \mathrm{C}$ at the time of $1: 00 \mathrm{pm}$. The maximum value for convective heat transfer coefficient $\left(\mathrm{h}_{\mathrm{cw}}\right)$ in forced type solar still is $1.035 \mathrm{~W} / \mathrm{m}^{20} \mathrm{C}$ at the time of $4: 00 \mathrm{pm}$. The maximum value for Dunkle convective heat transfer coefficient $\left(\mathrm{h}_{\mathrm{cwDunkle}}\right)$ in natural type solar still is $2.69 \mathrm{~W} / \mathrm{m}^{20} \mathrm{C}$ at the time of 02:00 pm. The maximum value for Dunkle convective heat transfer coefficient $\left(\mathrm{h}_{\mathrm{cwDunkle}}\right)$ in forced type solar still is $2.85 \mathrm{~W} / \mathrm{m}^{20} \mathrm{C}$ at the time of 02:00 pm. 


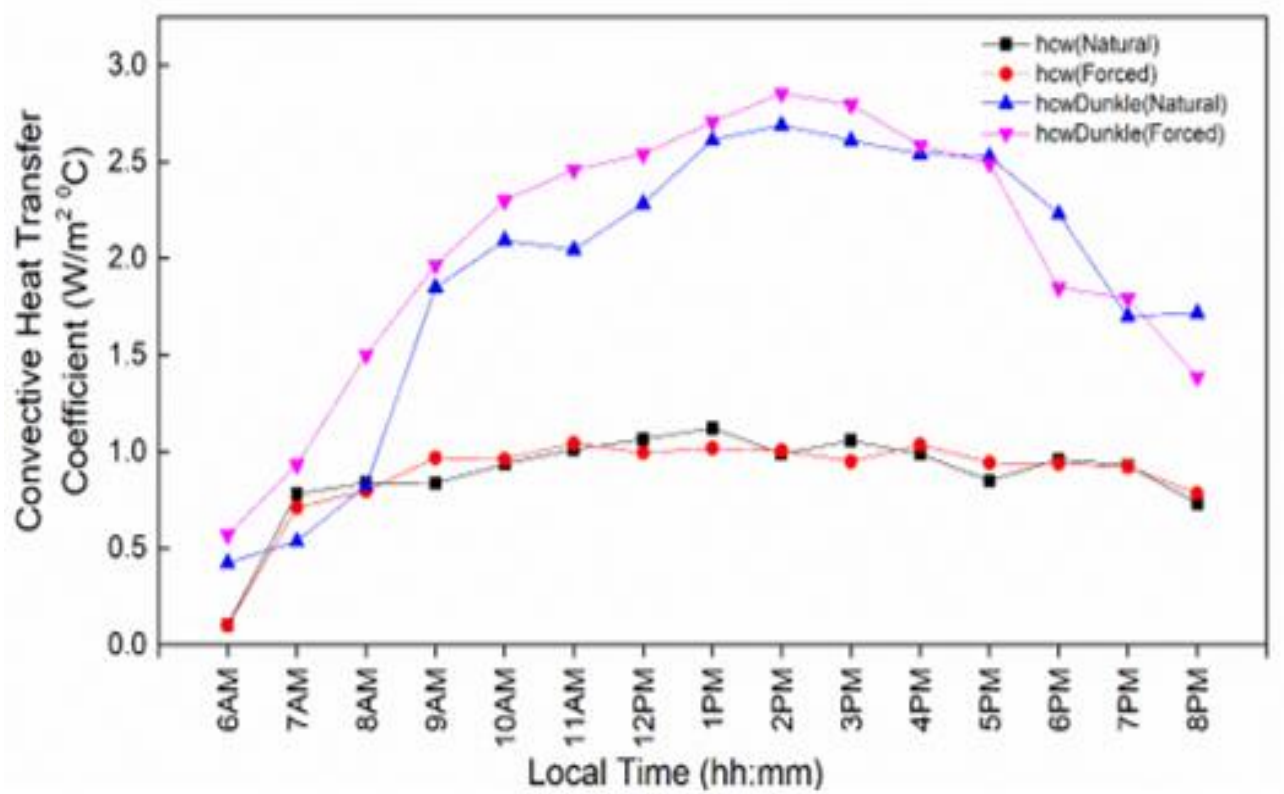

(A)

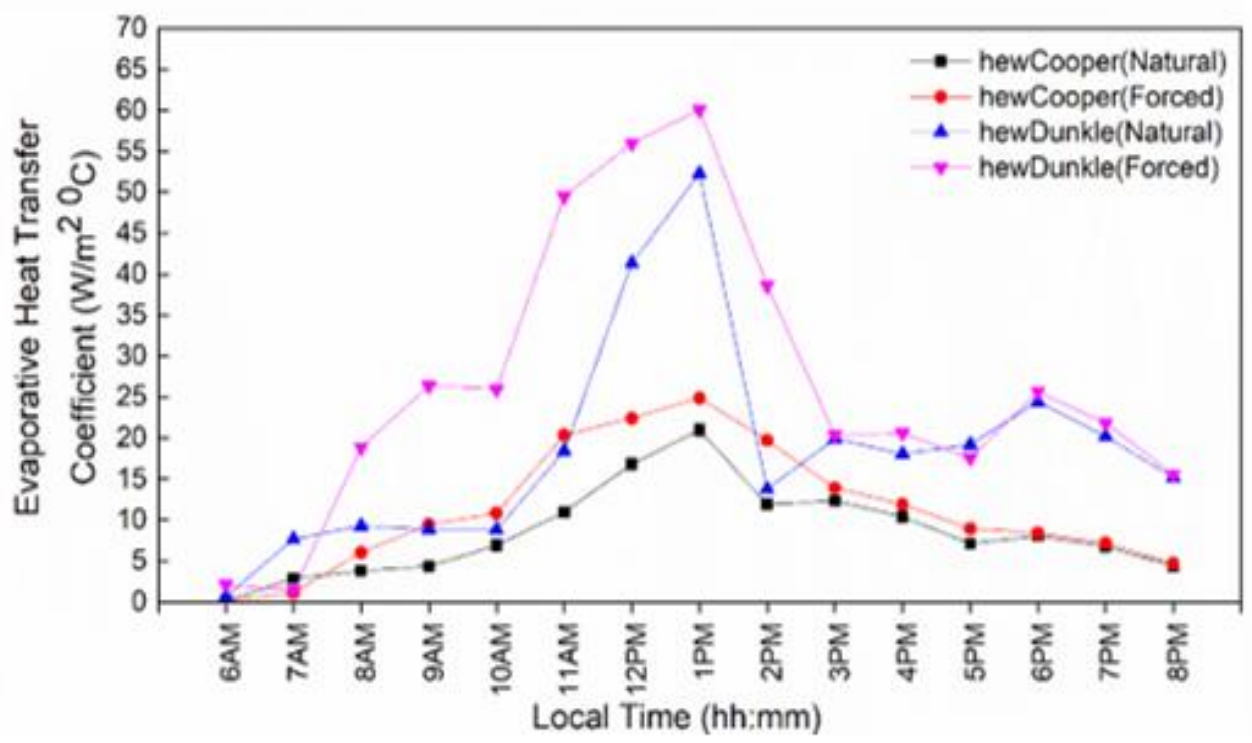

(B)

Figure 7. Variation of Internal heat transfer coefficient with time

(A) Convective heat transfer coefficient (B) Evaporative heat transfer coefficient

The maximum value for Cooper evaporative heat transfer coefficient $\left(\mathrm{h}_{\mathrm{ewCoper}}\right)$ in natural type solar still is $20.97 \mathrm{~W} / \mathrm{m}^{2}{ }^{0} \mathrm{C}$ at the time of 1:00 pm as shown in Figure 7(B). The maximum value for Cooper evaporative heat transfer coefficient ( $\mathrm{h}_{\text {ewCooper}}$ ) in forced type solar still is $24.88 \mathrm{~W} / \mathrm{m}^{2}{ }^{0} \mathrm{C}$ at the time of 1:00 pm. Maximum value for Dunkle evaporative heat transfer coefficient ( $h_{\text {ewDunkle }}$ ) in natural type solar still is $52.30 \mathrm{~W} / \mathrm{m}^{20} \mathrm{C}$ at the time of 1:00 pm. The maximum value for Dunkle evaporative heat transfer coefficient ( $\mathrm{h}_{\text {ewDunkle }}$ ) in forced type solar still is $60.06 \mathrm{~W} / \mathrm{m}^{2}$ ${ }^{0} \mathrm{C}$ at the time of $1: 00 \mathrm{pm}$. 


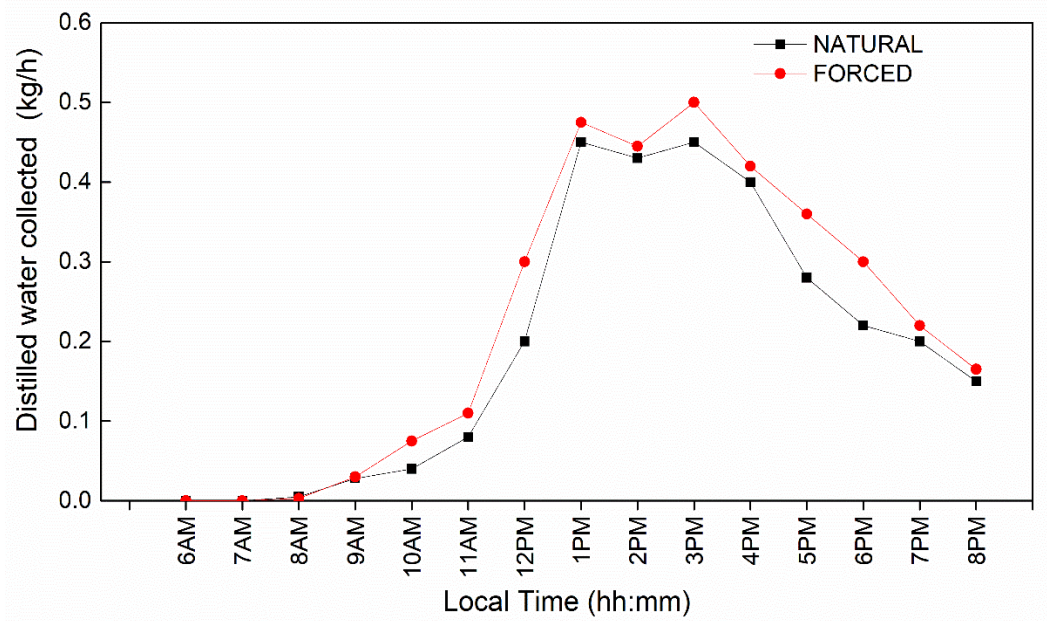

Figure 8. Hourly collected distillate water

Figure 8 represents the rate of distillate water collected with respect to time. Higher distillate output can be achieved in forced type solar still than natural type solar still because of extra energy source as shown in Figure 8. In the natural type solar still, the maximum rate of distillate water collected is $0.45 \mathrm{~kg} / \mathrm{hr}$ at the time interval between 1:00 pm to 2:00 pm and the similar rate were found in a time interval of 3:00 pm to 4:00 pm. In the forced type solar still, the maximum rate of distillate water collected is $0.5 \mathrm{~kg} / \mathrm{hr}$ at the time interval between 3:00 pm to 4:00 pm.

\section{CONCLUSIONS, IMPLICATIONS AND LIMITATIONS OF THE STUDY}

The results obtained for heat transfer coefficients are better in forced type solar still than the natural type of solar still setup.

1. From the Figure 5(A) shows that overall thermal efficiency of forced convection is higher than natural convection. In addition, 50\% increased overall thermal efficiency was observed in forced convection.

2. The hourly efficiencies with respect to time for both forced convection and natural convection gradually rise with the starting of the day and attain a maximum value of $77.61 \%$ and $58.97 \%$ respectively in the evening and then gradually declines.

3. In the external heat transfer coefficients, the convective heat transfer coefficient attains its peak value at the middle of the day, and it decreases as the day passes on. In natural convection, the maximum value achieved is in the middle of the day and declines afterwards. The radiative heat transfer coefficient is maximum at the middle of the day and decreases hourly with time for both natural and forced type solar still.

4. In the internal heat transfer coefficients, the convective heat transfer for both natural and forced type solar still shows similar values of $h_{\mathrm{cw}}$ throughout the day. However, vital fluctuations can be seen in Dunkle heat transfer coefficient $\left(\mathrm{h}_{\text {cwdunkle }}\right)$ at the starting of the day, and it attains the peak value in the middle for both natural and forced type solar still. In the evaporative heat transfer coefficient, forced type solar still showed better values than natural type solar still in terms of Cooper evaporative heat transfer coefficient $\left(\mathrm{h}_{\text {ewcooper }}\right)$ with the maximum value obtained in the middle of the day gradually decreasing till the evening time. However, the values for Dunkle evaporative heat transfer coefficient ( $h_{\text {ewdunkle }}$ ) attain peak value in the middle of the day, and the values decrease gradually up till the evening time.

5. The rate of water distillate collected in the natural convection heat transfer is $0.45 \mathrm{~kg} / \mathrm{hr}$ at 2:00 $\mathrm{pm}$ and 0.5 $\mathrm{kg} / \mathrm{hr}$ at 3:00 pm for forced convection. Clearly forced type solar still has a higher rate of the distillation of water compared to natural type solar still.

6. The findings in the present research work have several implications. Firstly, the results will help in identifying all root causes which can alter or affect the efficiency and performance of solar stills. Secondly, the hourlybased study will provide better clarification regarding the heat transfer and its intensity if similar work is done for any other season or month. 
7. However, there are also few limitations of the research such as the study is carried out during the winter season of the year in January where the solar intensity is low compared to other months. The solar collector used in the setup is a flat plate type; hence; the readings are confined to working conditions of a flat plate collector.

\section{ACKNOWLEDGEMENT}

One of the authors, Anshika Rani, is thankful to Ministry of Human Resources and Development (MHRD) and Maulana Azad National Institute of Technology (MANIT) Bhopal, India for providing research fellowship and other facilities for compiling this work. Authors are also grateful to the Department of Mechanical Engineering, Delhi Technological University, Delhi for providing computational facilities.

\section{NOMENCLATURE}

$q_{c w}$

$h_{c w}$

$A_{s}$

$A_{c}$

$\Delta T$

$L$

$T_{g}$

$T_{w}$

$I_{g r}$

$I_{d r}$

$h_{w}$

$(M C)_{w}$

$T_{a}$

$h_{c w}$

$h_{\text {cwDunkle }}$

$h_{e w}$

$\mathrm{h}_{\text {ewCooper }}$

$h_{r w}$

$h_{r g}$

$h_{c g}$

$T_{c i}$

$K_{g}$

$T_{c o}$

$M_{w}$

$C_{w}$

$A_{b}$

$A_{s}$

$N_{u}$

$G_{r}$

$P_{r}$

$g$

$P_{\text {igs }}$

$P_{w}$

$\eta \mathrm{i}$

W

Greek Symbols

\section{$\varepsilon_{w}$}

$\varepsilon_{g}$

$\varepsilon_{f f}$

$\sigma$

$\beta$
Convective heat transfer rate, $\mathrm{W} / \mathrm{m}^{2}$

Evaporative heat transfer coefficient, $\mathrm{W} / \mathrm{m}^{2} \mathrm{~K}$

Area of the basin of the solar still, $\mathrm{m}^{2}$

Area of the Solar collector, $\mathrm{m}^{2}$

Temperature difference between water and inner glass cover, ${ }^{0} \mathrm{C}$

Latent heat of vaporization, $\mathrm{J} / \mathrm{kg}$

Glass temperature, ${ }^{0} \mathrm{C}$

Water temperature, ${ }^{0} \mathrm{C}$

Solar radiation on the glass cover of the solar still, $\mathrm{W} / \mathrm{m}^{2}$

Diffused solar radiation, $\mathrm{W} / \mathrm{m}^{2}$

Convective heat transfer coefficient from basin liner to water, $\mathrm{W} / \mathrm{m}^{20} \mathrm{C}$

Heat capacity of water $/ \mathrm{m}^{2}$ in basin, $\mathrm{J} / \mathrm{kg}{ }^{0} \mathrm{C}$

Ambient temperature, ${ }^{0} \mathrm{C}$

Convective heat transfer coefficient from water surface to glass, $\mathrm{W} / \mathrm{m}^{20} \mathrm{C}$

Convective heat transfer coefficient from water surface to glass by Dunkle's relation, $\mathrm{W} / \mathrm{m}^{2}{ }^{0} \mathrm{C}$

Evaporative heat transfer coefficient from water surface to glass, $\mathrm{W} / \mathrm{m}^{2}{ }^{0} \mathrm{C}$

Evaporative heat transfer coefficient from water surface to glass by Cooper's relation, $\mathrm{W} / \mathrm{m}^{2}{ }^{0} \mathrm{C}$

Radiative heat transfer coefficient from water to glass, $\mathrm{W} / \mathrm{m}^{20} \mathrm{C}$

Radiative heat transfer coefficient from glass cover to the outside atmosphere, $\mathrm{W} / \mathrm{m}^{20} \mathrm{C}$

Convective Heat transfer coefficient from glass cover to the outside atmosphere, $\mathrm{W} / \mathrm{m}^{2}{ }^{0} \mathrm{C}$

Temperature of inner surface of glass, ${ }^{\circ} \mathrm{C}$

Thermal conductivity of glass, $\mathrm{W} / \mathrm{mK}$

Temperature of outer surface of glass, ${ }^{\circ} \mathrm{C}$

Mass of water, $\mathrm{kg}$

Specific heat of water, $\mathrm{J} / \mathrm{kg} \mathrm{K}$

Area of basin liner, $\mathrm{m}^{2}$

Area of sidewalls losing heat, $\mathrm{m}^{2}$

Nusselt Number

Grashof Number

Prandlt Number

Gravity acceleration $\left(\mathrm{m} / \mathrm{s}^{2}\right)$

Partial saturated vapor pressure at inner glass temperature, N/m

Partial saturated vapor pressure at water temperature, $\mathrm{N} / \mathrm{m}^{2}$

Hourly efficiency (\%)

Uncertainty

Emissivity of water (0.95)

Emissivity of glass cover (0.94)

Effective emissivity

Stephan Boltzman constant

$\left(\mathrm{K}^{-1}\right)$ 


\section{REFERENCES}

[1] Agrawal A, Rana RS, Srivastava PK. Heat transfer coefficients and productivity of a single slope single basin solar still in Indian climatic condition: Experimental and theoretical comparison. Resource-Efficient Technologies. 2017 Dec 1;3(4):466-82. https://doi.org/10.1016/j.reffit.2017.05.003.

[2] Tripathi R, Tiwari GN. Effect of water depth on internal heat and mass transfer for active solar distillation. Desalination. 2005 Mar 10;173(2):187-200. https://doi.org/10.1016/j.desal.2004.08.032.

[3] Sandeep A, Archana K, Ellappan S, Mallesham D. Advancement Of Solar Selective Dlc Coating Using Capvd For Solar Thermal Applications. Journal of Thermal Engineering. 2020 Jul;6(4):422-37. https://doi.org/10.18186/thermal.734719.

[4] Mahian O, Kianifar A, Jumpholkul C, Thiangtham P, Wongwises S, Srisomba R. Solar distillation practice for water desalination systems. Journal of Thermal Engineering. 2015 Oct 1;1(4):287-8. https://doi.org/10.18186/jte.93924.

[5] Rani A, Suresh S, Kumar A. (2019). Different Techniques for Separation of Brackish Water. Asian Journal of Chemistry 31 (1), 9-17. https://doi.org/10.14233/ajchem.2019.21614.

[6] Tiwari AK, Tiwari GN. Effect of water depths on heat and mass transfer in a passive solar still: in summer climatic condition. Desalination. 2006 Aug 5;195(1-3):78-94. https://doi.org/10.1016/j.desal.2005.11.014.

[7] Rahbar N, Esfahani JA. Estimation of convective heat transfer coefficient in a single-slope solar still: a numerical study. Desalination and water treatment. 2012 Dec 1;50(1-3):387-96.

[8] Kumar S, Tiwari GN. Estimation of convective mass transfer in solar distillation systems. Solar energy. 1996 Dec 1;57(6):459-64.

[9] Khaoula H, Ali B, Bechir C, Sathyamurthy R. Comparative Study for Evaluation of Mass Flow Rate for Simple Solar Still and Active with Heat Pump. Journal of Water and Environmental Nanotechnology. 2017 Jul 1;2(3):157-65. https://doi.org/10.22090/JWENT.2017.03.003.

[10] Kumar S, Tiwari GN. Estimation of internal heat transfer coefficients of a hybrid (PV/T) active solar still. Solar Energy. 2009 Sep 1;83(9):1656-67. https://doi.org/10.1016/j.solener.2009.06.002.

[11] Dwivedi VK, Tiwari GN. Comparison of internal heat transfer coefficients in passive solar stills by different thermal models: an experimental validation. Desalination. 2009 Sep 30;246(1-3):304-18. https://doi.org/10.1016/j.desal.2008.06.024.

[12] Phadatare MK, Verma SK. Effect of cover materials on heat and mass transfer coefficients in a plastic solar still. Desalination and Water Treatment. 2009 Feb 1;2(1-3):254-9. https://doi.org/10.5004/dwt.2009.290.

[13] Kumar KV, Bai RK. Performance study on solar still with enhanced condensation. Desalination. 2008 Sep 30;230(1-3):51-61. https://doi.org/10.1016/j.desal.2007.11.015.

[14] Sakthivel M, Shanmugasundaram S, Alwarsamy T. An experimental study on a regenerative solar still with energy storage medium—Jute cloth. Desalination. 2010 Dec 15;264(1-2):24-31. https://doi.org/10.1016/j.desal.2010.06.074.

[15] Chauhan PS, Kumar A, Nuntadusit C. Thermo-environomical and drying kinetics of bitter gourd flakes drying under north wall insulated greenhouse dryer. Solar Energy. 2018 Mar 1;162:205-16.

[16] Tiwari S, Tiwari GN. Thermal analysis of photovoltaic-thermal (PVT) single slope roof integrated greenhouse solar dryer. Solar Energy. 2016 Nov 15;138:128-36.

[17] Tiwari S, Tiwari GN, Al-Helal IM. Performance analysis of photovoltaic-thermal (PVT) mixed mode greenhouse solar dryer. Solar Energy. 2016 Aug 1;133:421-8. https://doi.org/10.1016/j.solener.

[18] Tiwari GN. Solar energy: fundamentals, design, modelling and applications $9^{\text {th }}$ edition, Narosha publishing house, New Delhi. 2012.

[19] Rani A, Suresh S, Kumar A. (2019). "Review on Thermal Modeling of Solar Desalination Systems." Research Journal of Chemistry 23(4), 90-102.

[20] Cooper PI. Digital simulation of experimental solar still data. Solar Energy. 1973 Mar 1;14(4):451-68. 